\title{
Ukrajina mimo Ukrajinu
}

ПЕЛЕНСЬКА, О.: Украӥна поза Украӥною. Енциклопедичний словник мистецького, культрурного і громадського життя українскої емиграції в міжвоєнній Чехословаччині (1919-1939). Прага: Національна бібліотека Чеської Республіки - Слов'янська бібліотека, Наукове Товариство ім. Шевченка в Канаді, Українсько-Канадський Дослідчо-Документаційний Центр, 2019. 331 с. ISBN 978-80-7050-713-1.

Téma ukrajinské diaspory/emigrace/imigrace stojí od 8o. let 20. století a zejména od vzniku samostatné Ukrajiny v roce 1991 ve středu pozornosti mezinárodní slavistiky obecně a ukrajinistiky zvláště. Češi mají v tématu Ukrajina, Ukrajinci a ukrajinština $\mathrm{v}$ jisté smyslu klíčové postavení. Ukrajinská duma uvedená v Blahoslavově čítance z roku 1571, Dobrovského úvahy o národním jazyce ${ }^{1}$, které později inspirovaly ukrajinské obrozence, jeho recenze Enejidy (Aeneis) Ivana Kotljarevského z r. 1814, J. Kollár, jenž vyjádřil názor, že maloruština je libozvučnější než ruština, vyjádření P. J. Šafař́k va Geschichte der slawischen Sprache und Literatur nach allen Mundarten (1826), J. Wenziga a jeho Slavische Volkslieder s charakteristikou maloruské poezie (1830), vyjádření J. Jungmanna, F. Palackého, Karla Havlíčka Borovského aj., počátky ukrajinské literatury v travestijní heroikomice, o níž tak přesvědčivě psal Karel Krejčí v Heroikomice v básnictví Slovanů (1964), ale také překládání v 19. století, z nichž se obvykle zdůrazňuje překlad Ševčenkova Kobzara (1872), aniž se zmiňuje slavná antologie moravského/brněnského polyglota Františka Vymazala (1841-1917) Slovanská poezije (Výbor z národního a umělého básnictva slovanského $v$ českých přkladech), jež vyšla roku 1874 a obsahovala také národní a umělou poezii maloruskou, tedy ukrajinskou, včetně dum, které se tu nazývají podle ruského (velkoruského) vzoru „historické písně“ (историческая песнь, obdoba našich kramářských písní), a včetně všech podstatných ukrajinských básníků až do té doby. Nemluvě o Masarykových vztazích k Ukrajině a Ukrajincům; je tu ovšem v novější době Ivan Franko, propojující novoromantismus, realismus a modernu, Olha Kobyljanská, propojující Rusko, Ukrajinu, střední Evropu a Francii. Nelze pominout klíčovou roli Ruské akce (o různých významech slova „ruský“ $\mathrm{z}$ historického hlediska snad není třeba mluvit),

1 V širším kontextu viz PRAŽÁK, R., KOVÁ̌̌, M.: fosef Dobrovský. Hungarista a ugrofinista. Brno: Masarykova univerzita, 2019. Kniha navazuje na předchozí výzkumy Richarda Pražáka (1931-2010), mj. na studii s podobným názvem z roku 1966. Viz také KÄFER, I., POSPÍŠIL, I. (eds): Brněnská hungaroslavistika a česko-slovensko-mad'arské vztahy. Segedín: Gerhardus Kaidó, 2012, a Slavica litteraria. 2011, č. 1. Hungaroslavica. Památce prof. PhDr. Richarda Pražáka, DrSc. (1931-2010). 
básnickou Pražskou školu na čele s Jevhenem Malanjukem, vztahy českých spisovatelů $\mathrm{k}$ ukrajinským právě $\mathrm{v}$ meziválečné době, po rozpadu SSSR mezinárodní konference o ukrajinské emigraci, rozsáhlé projekty, sborníky apod., spolupráci s ukrajinskými badateli na Ukrajině i jinde (Německo, Kanada, USA) atd. Nicméně nehledě na takřka konjunkturální témata, řadu vydaných knih a sborníků tu stále chybělo něco encyklopedického, komplexnějšího, věcného a faktograficky průkazného, co by synteticky shrnulo problematiku ukrajinské emigrace v meziválečném Československu. Tato kniha tím do značné míry je a za to patři autorce uznání.

Je zřejmé, že ukrajinská emigrace tvoří nedílnou součást emigrace jako takové v meziválečné ČSR, hlavně však emigrace východoslovanské, která byla podporována v rámci Masarykovy Ruské akce (vybudování vysokých škol včetně dvou univerzit, středních odborných škola a gymnázií, výzkumných zařízení apod.; o mnoha se $\mathrm{v}$ encyklopedii mluví). Zejména $\mathrm{v}$ ruském prostředí se dodnes objevují spekulace o zdroji financování této obrovské, náročné operace, a, jak se tvrdí, i Legiobanky, jímž měl být ruský zlatý poklad, který měly jistou dobu ve svém držení československé legie: píše se o tom $\mathrm{v}$ řadě ruských materiálů a tato spekulace hned tak $\mathrm{z}$ veřejného prostoru nezmizí, ale nemyslím, že to tak bylo a naši historikové to na základě dokumentů jasně vyvracejí (na webu je např. dostupná studie z pera vojenského historika Pavla Jaroslava Kuthana, roč. 1978, vycházející z pramenů²).

Př́tomná kniha je vskutku reprezentativní: finančně podpořená spoluvydavateli, jimiž jsou Národní knihovna ČR - Slovanská knihovna, kanadská Vědecká společnost T. Ševčenka a Ukrajinsko-kanadské badatelsko-dokumentační centrum, je vyrobena kvalitně, snad až na př́liš tě̌̌kém papíře, a má všechny náležitosti včetně atraktivních vyobrazení.

Nemělo by vcelku smysl vypočítávat, které osobnosti v tomto svazku, zahrnujícím období 1919-1939, tam jsou a proč, a které tam nejsou a z jakých př́ččn, ale zásadní námitky tento výběr nevzbuzuje; vše je velmi korektní. V jednotlivých heslech, jež jsou velmi dobře napsána, nechybějí osobnosti, instituce, umělecké skupiny, školy, vysoké a střední, spolky, organizace, politická hnutí a orgány, muzea, archívy, nesčetná periodika, časopisy, almanachy, sborníky, příležitostné tisky, a to nejen ukrajinské, ale i české a československé, jež se na činnosti Ukrajinců v diaspoře podílely, např. Národní galerie, sama Národní knihovna a její slovanská odnož, Památník národního písemnictví, archiv Kanceláře prezidenta republiky, časopis Slovanský přehled, ale také místa spojená s životem a posledním odpočinkem ukrajinských kulturních činitelů (Olšanské hřbitovy).

2 KUTHAN, P. J.: Ruský zlatý poklad a čs. legionárí. Valka.cz. <https://www.valka.cz/12579-Ruskyzlaty-poklad-a-cs-legionari>. [online]. [cit. 5. 5. 2020]. 
Mezi významnými jmény jsou tu mimo jiné: Jevhen Malanjuk, Olena Teliha, Hryhor Omelčenko, Stepan Smal-Stockyj, Mykola Nevrlyj (na kontakt s ním rád vzpomínám), Volodymyr Vynnyčenko, Leonid Bileckyj, Michajlo Hruševskyj, Orest Zilynskyj, Andrej Kornijčiuk, Taras Kuščynskyj, Jurij Klen (vl. jm. Oswald-Eckhart Burghardt), Bohdan Lepkyj; jsou tam však i jména př́ležitostných návštěvníků, kteří byli etnickými Ukrajinci, ale svou činností patří do jiného národního okruhu (mj. N.V. Gogol / M. Hohol). České osobnosti spjaté tak či onak s ukrajinskou československou emigrací jsou tu různé a také různé hodnotové a politické orientace, např. historik Jaroslav Bidlo, estetik, hudební vědec a kulturní činitel a politik Zdeněk Nejedlý, avantgardní teoretik a umělec Karel Teige, samozřejmě T. G. Masaryk a mnoho dalších. Poněkud mi tu chybějí jednak české univerzity a jejich slovenská sestra (není tu - pokud dobře čtu - ani Karlova ani Masarykova a ani Komenského), i když bych si nemyslel, že nemají s ukrajinskou meziválečnou emigrací nic společného, jednak Slovanský ústav, zařízení ministerstev národní osvěty a zahraničí, ale např. i kdysi slavné a respektované periodikum Slavia, ale možná jsem se jen nedokonale díval; meziválečné Československo byla mnohonárodní země a Praha byla česko-německá, i když v té době už více česká; byla nicméně centrem nejen české, ale i německé slavistiky, ale to nejkontroverznější období je 1939-1945. ${ }^{3}$ Víme, jaké problémy v česko-německé Praze měl vídeňský rodák René Wellek (1903-1995), syn českého otce a polsko-italské matky, když navštěvoval nejen českou Karlovu, ale také německou (germanistiku studoval na obou) Karlo-Ferdinandovu univerzitu, nebo Roman Jakobson, jenž si svi̊j titul PhDr. vydobyl na německé pražské univerzitě německy psanou prací o fonologii, podobnou té, již napsal francouzsky a jíž se později habilitoval na Masarykově univerzitě. Česko-německé univerzitní spory a třenice, např́klad o insignie, jsou všeobecně známé; René Wellek je barvitě líčí ve svých hovorech z přelomu 80. a 90. let minulého stoletít ${ }^{4}$ právě on, který se marně v té době pokoušel o česko-německé sblížení. Tedy spolupráce, zejména v Praze, musela být tak či onak vícenárodní

3 Viz SCHALLER, H.W.: Geschichte der slawischen und baltischen Philologie an der Universität Königsberg. Frankfurt a. M, 2009. SCHALLER, H. W.: Der Nationalsozialismus und die slawische Welt. Regensburg: Pustet, 2002. SCHALLER,H.W.: Ukrainistik in Europa. Peter Lang, 2013. SCHALLER, H. W.: Die „Reichsuniversität Posen “ 1941-1945: Vorgeschichte, Nationalsozialistische Gründung, Widerstand und Polnischer Neubeginn. Peter Lang, 2010. SCHALLER, H. W.: Slawische Kulturgeschichte: Entwicklungen, Tatsachen und Persönlichkeiten. Peter Lang, 2020.

4 DEMETZ, P.: A Conversation with René Wellek. A Yearbook of Central European Culture, 9. Ann Arbor: University of Michigan, 1990, s. 135-145. DEMETZ, P.: A Conversation with René Wellek. A Yearbook of Central European Culture, 10. Ann Arbor: University of Michigan, 1991, s. 235-251. DEMETZ, P.: A Conversation with René Wellek. A Yearbook of Central European Culture, 11. Ann Arbor: University of Michigan, 1992, s. 79-92. V našem překladu (Hovory Petera Demetze $z$ René Wellkem) se svolením autora: POSPÍŠIL, I.: Hovory Petera Demetze z René Wellkem. In: POSPÍŠIL, I., ZELENKA, M.: René Wellek a meziválečné Československo: ke kořenům strukturální estetiky. Brno: Masarykova univerzita, 1996, s. 111-149. 
a multilaterální. Encyklopedie ohromí množstvím hesel: jen ta začínající slovem „ukrajinský“ nebo „ukrajinská“ zabírají takřka 30 stran (228-256). Jsou to spolky, organizace, politické orgány apod. To ukazuje na obrovitou tematickou šiři ukrajinské činnosti v meziválečném Československu. Další problém souvisí s výběrem osob a jejich divergencí, nebot časový výsek, jenž autorka stanovila (ten je dán počátkem a koncem předválečného Československa), znamená, že heslo nemůže obsáhnout celý život př́slušné osobnosti, ale jen její aktivitu do roku 1939. Klíčovou postavou z české strany je tu ovšem T. G. Masaryk, původce Ruské podpůrné akce, jehož jméno se objevuje takřka u každého důležitějšího hesla; byl to skutečně pilíř československo-ukrajinské vzájemnosti. $Z$ uváděných významných kulturních činitelů se někteř́i usadili v ČSR jen na čas, potom směřovali jinam, jiní uprchli na poslední chvíli před blížící se Sovětskou armádou a jednotkami SMERŠ v roce 1945, často do Bavorska (Mnichov se posléze stal a do značné míry i dnes zůstává novým centrem zahraničních Ukrajinců), ale také jinam, do Francie, Spojeného království, USA, Kanady apod., jiní se zase vrátili do SSSR. Někteří byli sovětskými orgány - jako jejich ruští a běloruští kolegové - odvlečeni v roce 1945 do některého z gulagů, kde zahynuli, jiní se stali obětí čistek už po dobrovolném návratu do SSSR před rokem 1941, jiní se stali za války na sovětském území obětí nacistického vraždění, bylo to prostě různé. Samozřejmě je někdy záhadou, kteří z emigrantů - a to nejen ukrajinských se stali obětí sovětských orgánů a byli cíleně vyhledáváni, a kteří nejenže unikli, ale zůstali v Československu i po válce a byli personae gratissimae; to se - jako u mnoha dalších věcí $\mathrm{z}$ minulosti a prítomnosti - asi nedovíme. Určitě zajímavé by bylo sledovat činnost ukrajinských spolků a organizací za druhé Česko-Slovenské republiky a za Protektorátu Böhmen und Mähren a po válce i jinde, ale to by již šlo za rámec meziválečného Československa. Ne bez pohnutí vzpomínáme Ukrajinců, kteří zde žili a zanechali výrazné stopy ve vlastním ukrajinském okruhu, ale také mimo něj a tím přispěli k rozvoji české a slovenské kultury, vědy, umění, národního života jako celku, namnoze i po roce 1945 .

Další metodologický problém tkví v tom, nakolik se jednotlivé osoby podílely na ukrajinském životě v ČSR a nakolik silně se integrovaly jazykově a kulturně a stali se více či méně součástí většinových národů. Někdy to souviselo se změněnými hospodářskými a politickými poměry ve 3o. letech, zejména $v$ jejich druhé polovině (světová hospodářské krize, nástup A. Hitlera k moci, nové vztahy se SSSR - to vše samozřejmě negativně ovlivnilo politické postavení ukrajinské, ale také ruské a běloruské emigrace). Pozoruhodná jsou hesla obsahující informace o Češích, kteří se podíleli na činnosti ukrajinské emigrace v meziválečném Československu a na rozvoji jeho kultury: byli to někdy lidé s ukrajinskou „anamnézou“, tj. narození třeba na Volyni nebo v Podkarpatské Rusi, ale hlavně s Ukrajinci v ČR spolupracující a propagující jejich činnost (historici, spisovatelé, výtvarní umělci apod.). Je tu 
zachycena činnost ukrajinské emigrace nejen v českých zemích, ale také na Slovensku a Podkarpatské Rusi; jsou tu samozřejmě i pro někoho dosti kontroverzní osobnosti typu Avgustina Vološina (1874-1945, unesl ho SMERŠ, zemřel v Moskvě, údajně přirozenou, možná však i násilnou smrtí, od r. 2002 hrdina Ukrajiny). Značná pozornost je právem věnována Podkarpatské Rusi, která byla formální součástí obnovené ČSR v předmnichovských hranicích, ale 29. června 1945 byla pod silným mocenským tlakem postoupena Ukrajinské sovětské socialistické republice jako součásti SSSR. Rusínská otázka se tu neřeší, i když právě i u nás vyšly v poslední době na toto téma různé publikace. ${ }^{5}$

Metodologickým problémem je také to, koho zde pokládat za Ukrajince: najdeme tu N. V. Gogola (Mykolu Hohola), autora snad nejnacionalističtější velkoruské tirády v ruské literatuře v explicitu prvního dílu Mrtvých duší, který byl na Ukrajině v minulosti hodnocen různě, často protikladně, nyní byl vzat na milost i jako ruský spisovatel (byl na našem území v Karslbadu / Karlových Varech a Gräfenbergu / Lázních Jeseník, kde se léčil; o jeho ukrajinskosti není pochyb; pocházel z polsko-ukrajinské drobné šlechty, v současnosti o jeho původu vznikly celé genealogické letopisy), naopak tu nenajdeme rodinu Vilinských (Serhije/Sergije, smluvního a po roce 1945 řádného profesora Masarykovy univerzity, a jeho syna Valerije, muže složitého a tragického osudu), kteří sice mluvili a psali víceméně jen rusky, ale o jejichž původu také není pochyb. ${ }^{6}$ Otázka je, nakolik by se měla odlišovat návštěva nebo návštěvy území bývalého Československa od trvalejšího pobytu, ale na druhé straně pro poznání široké spolupráce národů je každá taková zmínka cenná. Každé heslo obsahuje i sekundární literaturu, kde se ovšem setkáváme s různými deficity, ale ani to není podstatné.

Kniha vyšla s finanční podporou uvedených institucí péčí Slovanské knihovny NK ČR ukrajinsky. Nepochybně by si zasloužla i českou a snad i slovenskou mutaci, která by však měla přihlédnout $\mathrm{k}$ specifiku československých (českých a slovenských) poměrů a vyjít tomu vstříc i faktograficky, metodologicky a koncepčně. Zde by se nabízelo rozšriřené zkoumání spojené s řadou delikátních a kontroverzních otázek, ale také velká plocha vzájemných vztahů různých emigrací na území meziválečné ČSR

5 Viz např. naši recenzi na reprezentativní knihu: POSPÍŠIL, I.: Pavel Robert Magocsi: Národ odnikud. Ilustrované dějiny karpatských Rusínů. Proudy, 2014, č. 2. <http://www.phil.muni.cz/journal/proudy/ filologie/recenze/2014/2/pospisil_magocsi_rusini.php>. [online]. [cit. 5. 5. 2020].

6 Viz řadu našich studií o Sergiji Vilinském, např. Sergij Vilinskij an der Masaryk-Universität in Brünn: Fakten und Zusammenhänge. Wiener Slavistisches Jahrbuch, Bd. 42, 1996, s. 223-230, Také: HULTSCH, A.: Ein Russe in der Tschechoslowakei. Leben und Werk des Publizisten Valerij S. Vilinskij (1903-1955). Köln: Böhlau, 2011. POSPÍŠIL, I.: Rodina Vilinských v Československu: Valerij Vilinskij k některým jevưm české literatury. Slavica litteraria, 2017, č. 2, s. 39-47; POSPÍŠIL, I.: Ruský emigrant se divá na meziválečné Československo a česko-slovenský vztah. In: POSPÍŠIL, I. (ed.): Český a slovenský kulturní a politický prostor (vzájemnost - nevzájemnost, vstřícnost - rezistence, ústup - expanze). Brno: Česká asociace slavistů, Jan Sojnek - Galium, 2017, s. 151-161. 
a také vztah k domácímu politickému a kulturnímu prostředí - a to nejsou témata z nejlehčích, ale o to jsou důležitější. Tedy nejen vzájemnost, ale také nevzájemnost; částečně jsem se o to pokusil u česko-slovenských vztahů v rámci více než dvaceti brněnských česko-slovenských konferencí, ale i u emigrace ruské.?

Celkem vzato: Jde o velmi potřebnou knihu a již samo napsání a vydání zasluhuje obdiv. Je dobře, že se ukrajinské instituce $\mathrm{v}$ zámoří nepřestávají starat o ukrajinské kulturní dědictví meziválečného období a stejně tak Slovanská knihovna, jejíž ediční výkony v posledních desetiletích sledujeme s obdivem.

Ivo Pospíšil

\section{Literatura:}

DEMETZ, P.: A Conversation with René Wellek. A Yearbook of Central European Culture, 9. Ann Arbor: University of Michigan, 1990, s. 135-145.

DEMETZ, P.: A Conversation with René Wellek. A Yearbook of Central European Culture, 10. Ann Arbor: University of Michigan, 1991, s. 235-251.

DEMETZ, P.: A Conversation with René Wellek. A Yearbook of Central European Culture, 11. Ann Arbor: University of Michigan, 1992, s. 79-92.

KÄFER, I., POSPÍŠIL, I. (eds): Brněnská hungaroslavistika a česko-slovensko-mad’arské vztahy. Segedín: Gerhardus Kaidó, 2012.

HULTSCH, A.: Ein Russe in der Tschechoslowakei. Leben und Werk des Publizisten Valerij S. Vilinskij (1903-1955). Köln: Böhlau, 2011.

KUTHAN, P. J.: Ruský zlatý poklad a čs. legionáři. Valka.cz. <https://www.valka.cz/ 12579-Rusky-zlaty-poklad-a-cs-legionari>. [online]. [cit. 5. 5. 2020].

PELENS'KA, O.: Ukrajina poza Ukrajinoju: encyklopedyčnyj slovnyk mystec'koho, kul'turnoho ì hromads'koho žyttja ukrajins'koji emihraciji v mižvojennij Čechoslovaččyni

7 POSPÍŠIL, I., ZELENKA, M. (eds): Česko-slovenská vzájemnost a nevzájemnost. Brno: Ústav slavistiky Filozofické fakulty Masarykovy univerzity, 20oo. Viz také naše studie: POSPIŠIL, I.: Fenomen svjazi literaturovedenija i literaturnogo tvorčestva: Jevgenij Ljackij i Jevgenij Vodolazkin na kontekstual'nom fone. In: Universalii russkoj literatury 6. Sbornik statej. Voronež: Izdatel'sko-poligrafičeskij centr „Naučnaja kniga“, 2015, s. 227-244. POSPIŠIL, I.: Naučnaja sudba Sergija Vilinskogo: samorealizacija učenogo-emigranta v čužoj srede. In: Pytannja literaturoznavstva, Černivcy, vyp. 92, s. 35-46. POSPIŠIL, I.: Chudožestvennaja kvintessencija pražskogo emigrantskogo opyta v romane fevgenija Ljackogo „Tundra“. In: Pytannja literaturoznavstva, 2015, vyp. 91, Černivci, s. 98-109. POSPIŠIL, I.: Brnenskaja sudba Romana Jakobsona v prizme vota separata. In: Pytannja literaturoznavstva. Černivcy, vyp. 94, 2016, s. 68-81. 
(1919-1939). Praha: Nacìonal'na bìblìoteka Čes'koji Respubliky - Slov’jans'ka bìblioteka, 2019.

POSPIŠIL, I.: Brnenskaja sud'ba Romana fakobsona v prizme vota separata. In: Pytannja literaturoznavstva. Černivcy, vyp. 94, 2016, s. 68-81.

POSPIŠIL, I.: Fenomen svjazi literaturovedenija i literaturnogo tvorčestva: fevgenij Ljackij

i Jevgenij Vodolazkin na kontekstual'nom fone. In: Universalii russkoj literatury 6. Sbornik statej. Voronež: Izdatel'sko-poligrafičeskij centr „Naučnaja kniga“, 2015, S. $227^{-244}$.

POSPÍŠIL, I.: Hovory Petera Demetze z René Wellkem. In: POSPÍŠIL, I., ZELENKA, M.: René Wellek a meziválečné Československo: ke kořenům strukturální estetiky. Brno: Masarykova univerzita, 1996, s. 111-149.

POSPIŠIL, I.: Chudožestvennaja kvintessencija pražskogo emigrantskogo opyta v romane Jevgenija Ljackogo „Tundra“. In: Pytannja literaturoznavstva, 2015, vyp. 91, Černivci, S. 98-109.

POSPIŠIL, I.: Naučnaja sudba Sergija Vilinskogo: samorealizacija učenogo-emigranta $v$ čužoj srede. In: Pytannja literaturoznavstva, Černivcy, vyp. 92, s. 35-46.

POSPÍŠIL, I.: Pavel Robert Magocsi: Národ odnikud. Ilustrované dějiny karpatských Rusinů. Proudy, 2014, č. 2. <http://www.phil.muni.cz/journal/proudy/filologie/ recenze/2014/2/pospisil_magocsi_rusini.php>. [online]. [cit. 5. 5. 2020].

POSPÍŠIL, I.: Rodina Vilinských v Československu: Valerij Vilinskij k některým jevům české literatury. Slavica litteraria, 2017, č. 2, s. 39-47.

POSPÍŠIL, I.: Ruský emigrant se dívá na meziválečné Československo a česko-slovenský vztah. In: POSPÍŠIL, I. (ed.): Český a slovenský kulturní a politický prostor (vzájemnost - nevzájemnost, vstřícnost - rezistence, ústup - expanze). Brno: Česká asociace slavistů, Jan Sojnek - Galium, 2017, s. 151-161.

POSPÍŠIL, I.: Sergij Vilinskij an der Masaryk-Universität in Brünn: Fakten und Zusammenhänge. Wiener Slavistisches Jahrbuch, Bd. 42, 1996, s. 223-230.

POSPÍŠIL, I., ZELENKA, M. (eds): Česko-slovenská vzájemnost a nevzájemnost. Brno: Ústav slavistiky Filozofické fakulty Masarykovy univerzity, 2000.

PRAŽÁK, R., KOVÁ̌̆, M.: Josef Dobrovský. Hungarista a ugrofinista. Brno: Masarykova univerzita, 2019.

SCHALLER, H. W.: Der Nationalsozialismus und die slawische Welt. Regensburg: Pustet, 2002

SCHALLER, H. W.: Die „Reichsuniversität Posen“ 1941-1945: Vorgeschichte, Nationalsozialistische Gründung, Widerstand und Polnischer Neubeginn. Peter Lang, 2010.

SCHALLER, H. W.: Geschichte der slawischen und baltischen Philologie an der Universität Königsberg. Frankfurt a. M, 2009.

SCHALLER, H. W.: Slawische Kulturgeschichte: Entwicklungen, Tatsachen und Persönlichkeiten. Peter Lang. 2020. 
SCHALLER, H. W.: Ukrainistik in Europa. Peter Lang, 2013.

Slavica litteraria. 2011, č. 1. Hungaroslavica. Památce prof. PhDr. Richarda Pražáka, DrSc. (1931-2010).

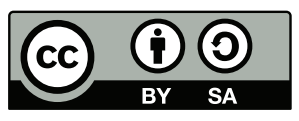

Toto dílo Ize užít v souladu s licenčními podmínkami Creative Commons BY-SA 4.0 International (<https:// creativecommons.org/licenses/by-sa/4.0/legalcode>). Uvedené se nevztahuje na díla či prvky (např. obrazovou či fotografickou dokumentaci), které jsou v díle užity na základě smluvní licence nebo výjimky či omezení príslušných práv.

https://doi.org/10.5817/OS2020-1-13

\section{N. V. Gogol v proudu literárního vývoje}

КРИВОНОС, В.Ш.: Гоголь в русском литературном пространстве XIX-XX вв. Самара: Министерство образования и науки Российской Федерации, Федеральное государственное образовательное учреждение высшего образования «Самарский государственный социально-педагогический университет», 2017. 268 c. ISBN 978-5-8428-1095-6.

Monografie jednoho z největších současných ruských znalců Gogolovy tvorby, samarského profesora Vladislava Šajeviče Krivonosa, by se asi dala snadno nazvat vzorovou přehlídkou toho, jak Gogol tvořivě čerpal z inspiračních zdrojů druhých autorů a jak jiní autoři čerpali inspiraci z jeho děl, a to nejen po formální stránce.

Ve 14 minuciózně zpracovaných studiích se autor zabývá zcela konkrétními místy jím zvolených literárních děl a prokazuje jak mimořádnou znalost Gogolových textů, tak stejně dobrou znalost textů děl těch autorů, jež do souvislosti s Gogolovou tvorbou dává. Díky tomu pak poukazuje na tematické či typologické souvislosti, at již záměrné nebo někdy zřejmě spíše intuitivní. Každá z kapitol - či spíše ze studií - je věnována konkrétnímu srovnání Gogolových textů s texty řady jeho předchůdců, současníků i následníků, přičemž samozřejmě nepretenduje na úplnost a na postižení všech možných pohledů.

Podstatné je, že díky srovnání zvolených textů dokáže V. S. Krivonos najít doložitelné společné znaky zkoumaných děl. Tak např. pro postavy Čackého v Gribojedovově Hoři z rozumu a Čičikova z Gogolových Mrtvých duši tyto sjednocující rysy nachází v obracení se ke kategorii rozumu, byte, jak autor monografie konstatuje, se její základní existenciální a ontologické traktování vztahuje u Gribojedova k filozofické tradici, u Gogola pak k tradici mravoučné a religiózní (s. 29). Tradovaný inspirativní vliv 